
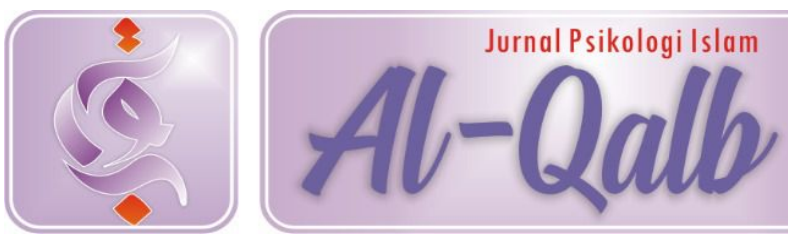

EISSN : 2686-326X

ISSN : 2085-8647

https://ejournal.uinib.ac.id/jurnal/index.php/alqalb/index

\title{
MAHABBAH DAN RUMANTIK PADA PASANGAN USILA
}

Received: $28^{\text {th }}$ March 2019; Revised: $14^{\text {th }}$ April 2019; Accepted: $27^{\text {th }}$ April 2019

\section{Putri Intan Purwari}

Universitas Islam Negeri Imam Bonjol Padang

Email: putripurwari@gmail.com

\section{Murisal}

Universitas Islam Negeri Imam Bonjol Padang

Email: dewimurisal@yahoo.com
Abstract: the purpose of this study is (1) to find out how the description of mahabbah and rumantik in the AN and $M$ pairs (2) to find out what factors make the $M$ and $A N$ families can live in an atmosphere of mahabbah and rumantik, and (3) to find out how the process the $M$ and $A N$ families embody mahabbah and rumantik households.

The method used in this study is a qualitative method with a case study model. Subjects consisted of 3 primary and secondary subjects. Data collection techniques through observation, interviews and documentation. The data analyst used the analysis of Miles \& Huberman.

The results of the study show that these elderly couples generally fulfill all aspects and indicators of mahabbah. As a supporting factor this couple can live in an atmosphere of mahabbah and rumantik are good at understanding their respective situations and conditions, mutual understanding, being honest, can correct themselves each, easy to forgive and is good at controlling emotions. The process embodies mahabbah and rumantik households that are equally trying between each other both in terms of the economy and the faithful of this couple.

Keywords: Mahabbah, Rumantik, Pasangan Usila

\section{PENDAHULUAN}

Usila (usia lanjut) merupakan suatu tahap perkembangan yang dialami oleh manusia yang tidak dapat dihindari lagi. Usila ditandai dengan perubahan fisik, emosional, maupun kehidupan seksual. Gejala-gejala kemunduran fisik seperti merasa cepat capek, stamina menurun, badan menjadi membongkok, kulit keriput, rambut memutih, gigi mulai rontok, fungsi pancaindra menurun, dan pengapuran pada tulang rawan (Maramis, 2016:27). Sedangkan menurut Bustan (dalam Maramis, 2016:29) perubahan mental emosional yaitu daya ingat menurun, sering lupa, emosi berubah, sering marah-marah, rasa harga diri tinggi, dan mudah tersinggung. Tidak hanya perubahan-perubahan bersifat negatif yang dialami oleh usila, akan tetapi perubahan yang bersifat positif juga dialaminya, seperti selalu meningkatkan iman dan takwanya kepada Tuhan, serta dapat menjalin hubungan tetap rukun dengan pasangan, anak-anak, kerabat dekatnya dan teman lingkungan untuk berkomunikasi dan bergaul. Berdasarkan data BKKBN Indonesia saat ini masuk ke dalam negara berstruktur penduduk tua (aging population) karena memiliki proporsi usia lanjut (usila) (60 tahun ke atas) yang besar (di atas 7\%). Dari data penduduk tersebut menunjukkan populasi usila cenderung meningkat setiap tahunnya, sehingga akan diikuti pula meningkatnya masalah usila, seperti usila mulai kehilangan pekerjaan, kehilangan tujuan hidup, kehilangan teman, resiko terkena penyakit, terisolasi dari lingkungan 
dan kesepian (http://www.bkkbn.go.id/.../ha ri-lanjut-usia-nasional-2017-membangu nkeluarga-pendidikan ) diakses pada tanggal 23/03/2018/ pukul 15. WIB).

Kesepian yang muncul pada usila dapat terjadi pada siapapun, baik itu usila yang tidak memiliki pasangan hidup, ataupun pada usila yang masih memiliki pasangan dalam menjalani kehidupannya. (Suardiman, 2011:35 ). Salah satu faktor penyebab dari kesepian karena usila merasa tidak mendapatkan figur kasih sayang dari pasangannya ataupun anaknya (Septiningsih \& Naimah, 2012:18). Selain penelitian di atas, Burs juga melakukan sebuah penelitian yang menjelaskan bahwa hubungan pernikahan tidak selalu harmonis, seorang yang menikah tidak dapat menyatakan bahwa orang tersebut tidak kesepian dalam menjalani hidupnya, kesepian dapat terjadi kerena hilangnya kontak atau komunikasi dengan orang lain terutama orang yang dicintai sehingga pasangan suami istri merasa tidak senang karena tidak adanya saling perhatian antara pasangan dalam menjalankan kehidupan rumah tangga (Septiningsih \& Naimah, 2012:20).

Dari hasil penelitian di atas dapat dipahami bahwa setiap usila akan rentan mengalami kesepian baik usila yang memiliki pasangan maupun tidak memiliki pasangan. Oleh karena itu seharusnya pasangan suami istri dapat memperbaiki hubungannya dengan menerapkan hubungan yang romantis hingga usia senja. Keromantisan merupakan sebuah hubungan yang penting bagi pasangan suami istri karena semakin bertambahnya usia pasangan suami istri, pasangan tersebut semakin membutuhkan perhatian yang kuat agar pasangan tidak kesepian dalam menjalani kehidupannya.

Menurut penelitian yang dilakukan Gupta, Pillai, Punetha dan Monah (2015:32) bahwa pasangan usia lanjut masih membutuhkan hubungan yang romantis namun hubungan romantis yang dibutuhkan seperti saling mengasihi, mampu melakukan kegiatan secara bersama-sama, saling menghormati, saling peduli satu sama lain, dan persahabatan. Sedangkan pada hasil penelitian di Negara Barat seperti Eropa dan Amerika bentuk romantis seringkali di tunjukkan ditempat umum seperti pada pengamatan yang dilakukan oleh Markey (2007:17) ketika pasangan usia lanjut sedang duduk di taman saling berpegangan tangan, berciuman dan berpelukan saling berbagi kasih sayang. Sedangkan kebanyakan romantis yang ada di Indonesia tidak ditunjukkan seperti itu karena perbedaan budaya. Seperti pada data awal yang didapatkan peneliti bahwa pasangan usia lanjut yang menjalani hubungan romantis menunjukkan bentuk romantis dengan saling memperhatikan, saling membantu dan mengerti kekurangan satu sama lainnya.

Keromantisan juga diselaraskan dengan rasa cinta yang mendalam, agar dalam menjalani biduk rumah tangga dapat menjalin hubungan yang harmonis. Stenberg (1986:35) mengatakan cinta adalah bentuk emosi manusia yang paling mendalam dan paling diharapkan. Cinta dapat terjadi pada siapa saja tanpa memandang usia. Cinta romantis menurut Bercheid \& Walster (dalam, Lopez 2007:23) adalah emosi kompleks yang bisa diurai menjadi yang terbaik kedalam kasih sayang dan pertemanan.

Menurut Imam Ghazali (dalam Kamsah \& Nazirah, 2004:21) mendefinisikan cinta sebagai suatu kecenderungan yang membawa kepada perasaan yang menyenangkan. Ibnu Qayyim al-jauziyyah menanggapi cinta sebagai sesuatu yang suci, tenang, utuh dan mengasyikkan (Kamsah \& Zahrin, 2004:21). Cinta dalam pandangan Imam Ghazali dan Ibnu Qayyim ini tergambar pada kehidupan Nabi SAW, di dalam rumah tangga beliau, kehidupan beliau merupakan Sesuatu yang amat perlu untuk dipelajari, dicermati, direnungkan dan diteladani, karena beliau adalah sebaikbaiknya panutan bagi semua muslim yang mengharapkan ridha Allah di dunia dan akhirat. Kehidupan beliau sangat perlu 
diteladani dalam berbagai hal diantaranya dalam hal keromantisan beliau bersama istriistri beliau. Mencontohi dan meniru cara Nabi memperlakukan istri dengan romantis dapat dilakukan diantaranya minum dalam satu gelas, saling menyuapi, mandi dalam satu bejana atau tidur dalam satu selimut bersama istri.

Rasulullah saw, dalam sejarahnya sangat romantis terhadap istri-istrinya dan tidak pernah melakukan perceraian terhadap istri-istrinya (Munadi, 2017:45). Seperti gambaran romantisme yang terjadi pada Rasulullah dengan istrinya, diistilahkan oleh From dengan sebutan Love way. Sedangkan dalam pandangan Islam diistilahkan dengan mahabbah. Love way atau mahabbah adalah hubungan antar pribadi yang dengannya dua orang menjadi satu. Perbedaan antara dua orang tidak lenyap ketika mereka mulai saling mencintai, dua kepribadian yang berbeda itu membentuk satu kepribadian baru (Palmquist, 2005:17). Sedangkan romantisme dalam bahasa Arab diistilahkan dengan rumantik. Rumantik merupakan cara untuk merealisasikan mahabbah melalui kehangatan, kasih sayang dan kelembutan.

\section{Aspek Mahabbah}

Cinta terlahir ataupun timbul dari dalam diri seorang individu karena ada sebab-sebab yang melahirkan cinta tersebut. Menurut (Al-Ghazali, 2007:23-34) cinta terbagi menjadi lima aspek diantaranya adalah:

a. Cinta terhadap diri sendiri

Pertama yang dicintai oleh manusia adalah dirinya sendiri, kemudian keselamatan anggota badannya, harta, anak, keluarga, dan teman-temanya. Seorang manusia tentu mencintai anggota badan dan menjaga keselamatan anggota badannya, karena kesempurnaan dan kelangsungan hidup juga terletak pada apa yang dicintai oleh manusia, Sedangkan harta dicintai karena ia merupakan sarana untuk kelangsungan dan kesempurnaan hidup. Manusia mencintai segala hal itu bukan karena substansi hal-hal tersebut, tetapi karena keterikatan hal-hal yang ada dalam mewujudkan kelangsungan dan kesempurnaan hidupnya.

b. Kebaikan

Manusia adalah budak kebaikan, manusia diciptakan dalam fitrah yang baik dan diciptakan untuk suka kepada hal-hal yang baik, begitu juga hati ia cenderung cinta terhadap orang yang berbuat baik kepadanya dan membenci orang yang berbuat jahat padanya. Orang baik yang dimaksud disini adalah orang yang suka menolong, cukup harta, tenaga, ilmu, dan faktor lainnya yang dapat mengukuhkan kelangsungan hidup sesamanya dan memberikan manfaat bagi kelestarian hidupnya. Hanya saja hal ini berbeda dengan anggota tubuh yang dicintai karena ia menyempurnakan fisik manusia, dan merupakan bentuk rill dari kesempurnaan yang dicari manusia, sedangkan orang yang berbuat baik bukanlah wujud kesempurnaan yang sebenarnya dicari, namun kadang-kadang, ia merupakan sarana terwujudnya kesempurnaan. Sebagaimana yang dijelaskan dalam sabda Rasulullah :

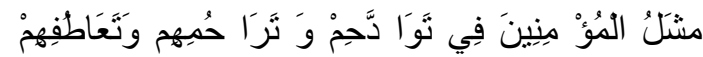

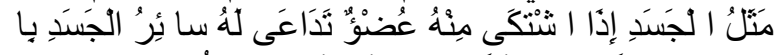

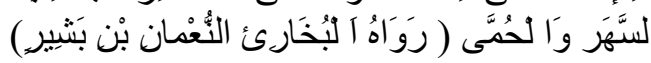

Artinya:

"Perumpamaan orang-orang mukmin dalam hal berkasih sayang dan saling cinta-mencintai adalah seperti sebatang tubuh. Apabila salah satu anggotanya mengadu kesakitan, maka seluruh anggota tubuh yang lain turut merasa sakit." (H . Al-Bukhari dari Nu'man bin Basyir).

Dari Hadist di atas mengandung arti bahwa sesama muslim dilandasi oleh prinsip saling tolong-menolong, menjaga keseimbangan, saling menanggung penderitaan dan saling memberi nasihat. 
c. Mencintai sesuatu karena sesuatu itu sendiri

Orang bisa mencintai sesuatu karena sesuatu itu sendiri, dan bukan karena mengharapkan suatu keuntungan lain dibalik cintanya. Sesuatu itu sendiri sudah merupakan wujud keuntungan baginya. Cinta semacam ini merupakan cinta hakiki yang telah mencapai tujuan sebenarnya dan dipercayai kelanggengannya. Cinta ini adalah seperti cinta pada keindahan dan kecantikan. Setiap keindahan dicintai oleh orang yang mengetahui letak keindahannya, dan cinta demikian muncul sebab keindahan itu sendiri. Hal ini karena mengetahui keindahan merupakan wujud kenikmatan itu sendiri. Sedangkan kenikmatan dicintai adalah karena esensi kenikmatan itu sendiri, dan bukan karena hal lain.

\section{d. Keindahan dan kecantikan}

Orang yang terpenjara dalam khayalan dan perasaan yang sempit terkadang menyangka bahwa keindahan dan kecantikan hanya berarti keserasian bentuk serta keindahan warna, putih yang bercampur merah, tinggi semampai dan lain-lain, yang bermuara pada sifat-sifat keindahan fisik manusia. Umumnya, keindahan bagi manusia adalah keindahan menurut penglihatan, kebanyakan mereka hanya memandang pada bentuk fisik seseorang. Mereka menyangka bahwa apa yang tak terlihat, tak terbayangkan, tak terbentuk, dan tak berwarna adalah sesuatu yang konseptual semata.

e. Keserasian yang tersembunyi antara pencinta dan yang dicintai

Keserasian antara orang yang mencintai dan yang dicintai, mereka saling cinta bukan karena keindahan fisik atau keuntungan tertentu yang bisa didapatkan, namun karena ada kecocokan jiwa. Cinta lahir dari kesamaan karakter jiwa, mereka saling melengkapi dan menggenapkan jiwa yang sama atau berbeda, bila saling melengkapi biasanya akan saling mencintai.

Gambaran mahabbah dan rumantik penulis temukan pada pasangan keluarga bapak AN dan ibu M. Mereka merupakan pasangan yang dulunya menikah pada usia muda, Bapak AN menikah pada usia 16 tahun dan Ibu M menikah pada saat berumur 15 tahun. Sekarang usia pernikahannya sudah mencapai 59 tahun dan telah dikaruniai 3 orang anak serta 9 orang cucu. Anak serta cucunya jarang mengunjungi Ibu $M$ dan Bapak AN, karena kesibukan dan jarak yang cukup jauh, anak mereka tinggal semua sudah pergi merantau, ada di Batam, di Tabek Patah dan di Lompatan.

Pada dasarnya mereka menikah bukan atas dasar kemauan dari mereka sendiri akan tetapi banyak faktor yang menyebabkan mereka menikah diusia muda diantara faktor tersebut adalah dijodohkan oleh kedua orang tua, pengaruh lingkungan dan budaya, maksudnya pasangan AN dan M ini memiliki sekelompok teman bermain sejak kecil. Mereka berdiskusi tentang masalah pernikahan siapa saja temantemannya yang sudah menikah pada masa itu, setelah diketahui ternyata semua temantemannya sudah menikah. Sedangkan mereka berdua belum menikah, dan belum mempunyai pasangan, akibatnya mereka dijodohkan oleh kedua orang tua mereka. Mendengar hal itu, orang tua mereka menjodohkan mereka berdua, ketika itu $\mathrm{M}$ berada di Asrama. Sampai satu minggu, akhirnya Ibu M memberi jawaban kepada orang tuanya kalau dirinya mau menikah dengan AN. Karena pada zaman dahulu kesucian dan keperawanan diagungkan di atas perkawinan. Kecocokan cinta dan perkawinan sering diatur oleh orang tua. Meskipun mereka menikah dijodohkan oleh orang tua mereka, hubungan mereka masih aman dan tentram sampai saat ini.

\section{Metode dan Rancangan Penelitian}


Tipe penelitian yang dilakukan adalah field research (penelitian lapangan) dengan mengunakan metode kualitatif, yang merupakan suatu prosedur penelitian yang menghasilkan data deskriptif berupa kata yang tertulis atau lisan dari orang yang diteliti. Dalam penelitian ini metode deskriptif adalah data yang dikumpulkan berupa kata-kata, gambaran bukan angkaangka atau memotret situasi sosial yang akan diteliti secara menyeluruh, luas dan mendalam (Sugiyono, 2010:209).

Model penelitian ini ialah model studi kasus yang merupakan suatu model yang menekankan pada eksplorasi dari suatu sistem yang terbatas (bounded system) pada satu kasus atau beberapa kasus secara mendetail, disertai dengan penggalian data secara mendalam yang melibatkan beragam sumber informasi yang kaya akan konteks (Herdiansyah, 2012:76)

\section{Sumber Data}

Sumber data dalam penelitian ini merupakan informan inti yaitu pasangan usila yang memiliki hubungan mahabbah dan rumantik yang mana peneliti menyebutnya sebagai subjek, kemudian informan tambahan adalah orang yang dapat memberikan informasi walaupun tidak langsung terlihat dalam penelitian yang diteliti seperti teman subjek, anak subjek, tetangga subjek yang bisa dijadikan data dalam penelitian ini.

\section{Teknik Pengambilan Data}

Supaya data yang didapatkan lebih akurat, maka ada beberapa teknik yang penulis lakukan dalam penelitian kualitatif ini, yaitu observasi, wawancara dan dokumentasi.

\section{Observasi}

Adapun metode dalam melakukan observasi ini menggunakan metode anecdotal record, yaitu metode yang digunakan, penulis melakukan obsevasi dengan hanya membawa kertas kosong untuk mencatat perilaku khas, unik, dan penting yang dilakukan subjek penelitian (Herdiansyah, 2012:133). Observasi ini dilakukan dengan cara mengamati aktivitas subjek, seperti apa dan bagaimana mahabbah dan rumantik subjek yang tergambar dari aspek-aspek mahabbah, dari kegiatan yang tengah dilakukan subjek.

\section{Wawancara}

Jenis wawancara yang peneliti gunakan ialah wawancara semi-terstruktur. Wawancara ini dilakukan kepada pasangan usila yang menjalin mahabbah dan rumantik yang merupakan informan inti dalam penelitian ini serta informan tambahan yaitu teman subjek, tetangga subjek dan lainnya. Penulis menggunakan guideline wawancara sebagai pedoman agar hasil yang di dapat relevan, terkait gambaran mahabbah dan rumantik pasangan usila ini.

\section{Dokumentasi}

Adapun dokumen yang peneliti gunakan ialah dokumen resmi, seperti kartu keluarga, kartu tanda penduduk, buku nikah subjek, serta foto-foto keseharian subjek.

\section{Analisis Data}

Analisis data merupakan tahap pertengahan dari serangkaian tahap dalam sebuah penelitian yang mempunyai fungsi yang sangat penting. Hasil penelitian yang dihasilkan harus melalui proses analisis data terlebih dahulu agar dapat dipertanggung jawabkan keabsahannya (Herdiansyah, 2012:158). Teknik analisis data yang ditemukan oleh Miles \& Huberman, yaitu pengumpulan data, reduksi data, display data, dan penarikan kesimpulan/verifikasi.

\section{Hasil}

Berdasarkan hasil analisis penelitian dan pembahasan tentang mahabbah dan rumantik pada pasangan usila di desa Lompatan Datar Kenagarian Barulak, maka sesuai dengan fokus penelitian peneliti dapat menarik kesimpulan sebagai berikut.

Pertama adapun gambaran mahabbah dan rumantik pada pasangan usila di desa Lompatan Datar Kenagarian barulak yaitu 
pasangan ini memenuhi seluruh aspek dan indikator yang ada pada mahabbah diantaranya:

1. Gambaran pada aspek cinta terhadap diri sendiri, hal ini dibuktikan karena pasangan ini menjaga keselamatan anggota badannya, menjaga keselamatan hartanya, menjaga anak-anaknya, menjaga keluarganya dan bisa mewujudkan kelangsungan hidupnya.

2. Gambaran pada aspek kebaikan, hal ini dibuktikan karena pasangan ini saling tolong-menolong dalam kehidupan rumah tangganya, saling memberikan nasehat, dapat mengukuhkan kelangsungan hidupnya dan memberikan manfaat bagi kelestarian hidupnya.

3. Gambaran pada aspek mencintai sesuatu karena sesuatu itu sendiri hal ini dibuktikan karena pasangan ini menerima kekasih apa adanya, mencintai kekasih setulus hati, menikmati kegembiraan bersama kekasih.

4. Gambaran pada aspek keindahan dan kecantikan, hal ini dibuktikan karena pasangan ini melihat kekasih dengan tersenyum, dan memberikan sesuatu yang berkesan.

5. Gambaran pada aspek keserasian yang tersembunyi antara pencinta dan yang dicintai, hal ini dibuktikan karena pasangan ini saling melengkapi antara satu sama lain dan pasangan ini memiliki kecocokan-kecocokan jiwa antara satu sama lain.

Kedua adapun faktor pendukung yang peneliti temukan sehingga pasangan usila ini bisa hidup dalam suasana mahabbah dan rumantik ketika menjalani kehidupan rumah tangga diantara faktor tersebut adalah:

1. Bisa memahami situasi dan kondisi masing-masing dalam menjalani kehidupan rumah tangga

2. Saling pengertian antara satu sama lain

3. Bersikap jujur

4. Bisa mengkoreksi diri masing-masing

5. Mudah memaafkan

6. Pandai mengontrol emosional

7. Menjalin komunikasi yang baik
8. Keterbukaan antar pasangan

9. Sabar

10. Tidak mencurigai antara satu sama yang lain

11. Agama

12. Dan faktor penyebab lainnya karena keseimbangan antara kewajiban dan hak sebagai suami dan istri dalam menjalani kehidupan rumah tangga dan pada akhirnya terwujud rumah tangga sakinnah mawaddah da warahmah (samara).

Ketiga adapun proses pasangan usila ini untuk mewujudkan rumah tangga yang mahabbah dan rumantik, pasangan ini dalam menjalani kehidupan rumah tangganya banyak hambatan-hambatan yang mereka lalui, baik hambatan dari keluarga, maupun hambatan dari segi ekonomi, akan tetapi karena mereka bisa menimalisir itu semua, sehingga dalam menjalani kehidupan rumah tangganya mereka tidak ambil pusing dan mereka percaya, bahwa Allah ada untuk menolong mereka dalam menjalani kehidupan rumah tangganya dalam mewujudkan nya mereka sama-sama berusaha antara satu sama lain baik dari segi ekonomi ataupun ketaqwaan pasangan ini.

Berdasarkan hasil penelitian yang penulis temukan, yang dikatakan dengan mahabbah dalam penelitian ini adalah perasaan yang timbul dalam diri seseorang yang diawali dengan makrifah karena akhlak baik yang ada pada orang tersebut sebagaimana akhlak baik yang ada pada pasangan $\mathrm{AN}$ dan $\mathrm{M}$ ini adalah ketakwaan, kepribadian serta sifat-sifat baik lainnya seperti jujur, sabar, saling menasehati, saling menghargai antara satu sama lain,sedangkan yang dikatakan dengan rumantik adalah kebersamaan antar pasangan, saling perhatian antara satu sama lain, saling menghargai dan kesetiaan.

\section{KESIMPULAN}

Dapat disimpulkan mahabbah dan rumantik menjalani pernikahan dalam pandangan Islam merupakan sebuah ikatan yang saling berhubungan satu dengan yang lainnya, kehidupan rumah tangga yang 
bahagia tidak akan pernah lepas dari seni (etika) dan keromantisan seperti kecintaan kemanjaan ucapan yang manis dan penuh kelembutan, ciuman penuh cinta, keterbukaan saling menyayangi, mencintai, mencumbu, serta saling menanggung beban bersama dan bersabar untuk mencapai terciptanya ketenangan, keteguhan, ketentraman hati, kenyamanan jiwa, dan kenyamanan pikiran

Hal ini juga dijelaskan dalam firman Allah (Qs. Ar-Rum: 21) sebagai berikut:

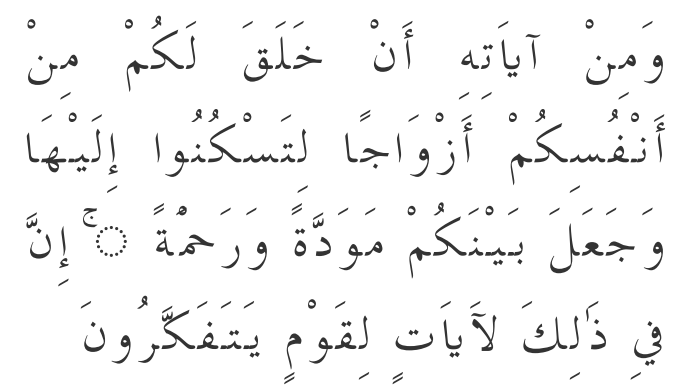
Artinya : Dan di antara tanda-tanda kekuasaan-Nya ialah Dia menciptakan untukmu isteri-isteri dari jenismu sendiri, supaya kamu cenderung dan merasa tenteram kepadanya, dan dijadikan-Nya diantaramu rasa kasih dan sayang. Sesungguhnya pada yang demikian itu benar-benar terdapat tanda-tanda bagi kaum yang berfikir.

Ayat diatas bertujuan agar keinginan dalam pernikahan tercapai dan mampu mewujudkan rumah tangga yang diinginkan dan sesuai harapan setiap pasangan suami istri maka harus diperhatikan tentang syaratsyarat tertentu agar tujuan perkawinannya dapat tercapai dan tidak menyalahi aturan yang telah ditetapkan agama.

Pernikahan bisa kandas ketika tidak didasari oleh rasa kesepahaman, kebersamaan, dan tanggung jawab bersama. Keutuhan rumah tangga dalam pernikahan harus dijaga dan dirawat, jangan sampai menjadi perceraian, sebab perceraian itu merupakan perkara yang halal tetapi di benci oleh Allah Swt. Segala apapun yang terjadi, terutama yang menjadi rahasia keluarga, jangan sampai tersebar pada orang lain, sekalipun kepada tetangga atau keluarga dekatnya. Untuk pasangan usila ini diharapkan bisa mempertahankan dan selalu memupuk mahabbah dan rumantiknya dalam menjalani kehidupan rumah tangga.

\section{DAFTAR KEPUSTAKAAN}

Ghazali. 2007. Kitab Al-Mahabbah wa AsySyau: Metode Menjemput Cinta. Diterjemahkan oleh : Abdurrasyid Ridha Bandung: PT Mizan Pustaka. Gupta, R. Pillai, V., Punetha, D. \& Monah, A. (2015). Love experiences of older african americans: a qualitative study. Journal of International Women's Studies, 16 (3), 287.

Herdiansyah, Haris. 2010. Metodologi Penelitian Kualitatif. Jakarta selatan:

Salemba Humanika.

https://www.bkkbn.go.id/.../hari-lanjut-usianasional-2017-membangunkeluarga-pendidikan ( 23 Maret 2018/ pukul 15.10 WIB).

Kamsah Fadzilah, \& Syaidatun Nazirah. 2004. Psikologi cinta. Malaysia: PTS Millennia.

Markey, M Patrick. 2007. Romantic Ideals, Romantic Obtainment and Relationship Experiences The Complementarity of Interpersonal Traits Among Romantic Partners. Amerika. Villanova University.

Maramis, R. 1. (2016). Kebermakanaan Hidup dan Kecemsan dalam Menghadapi Kematian pada Lansia di Panti Wedha Samarinda. ejournal Psikologi , 319-332.

Munadi, Radhie. (2017). Romantisme Nabi Muhammad dalam Perspektif Hadist. Skripsi. Makasar: UIN Alauddin Makassar.

Palmquist, Stephen. 2005. Fondasi Psikologi Perkembangan Menyelami Mimpi, Mencapai Kematangan Diri. Yogyakarta: Pustaka Belajar.

Septiningsih, D. S \& Naimah (2012). Kesepian pada lanjut usia: Studi 
70 Jurnal Al-Qalb, Jilid 10, Nomor 1, Maret 2019, hlm. 63-69

tentang Bentuk, Faktor Pencetus dan Strategi Koping. Jurnal Psikologi No 6

Stenberg, RJ. 1986. The Psychology of Love. USA: Yale University

Suardiman, Siti Partini. 2011. Psikologi Usia Lanjut. Yogyakarta: Gajah Mada University Press.

Sugiyono. (2014). Metodelogi penelitian Kuantitatif, Kualitatif. Bandung: Alfabeta. 